\title{
Profilaktyka kontrwywiadowcza w działalności Wojskowej Służby Wewnętrznej w latach 1957-1990
}

\section{Streszczenie}

Wojskowa Służba Wewnętrzna zastąpiła w strukturach Sił Zbrojnych budzącą lęk i nienawiść Informację Wojskową. Miała odgrywać jedynie rolę prewencyjną i informacyjną. Założenia te nosiły jednak piętno systemu totalitarnego. Formacji tej wyznaczono zadania kontrolne na wielu płaszczyznach. Wojskowa Służba Wewnętrzna zobowiązana została do realizowania czynności w zakresie kontrwywiadowczej ochrony Sił Zbrojnych celem zapobiegania rozpoznawaniu wojska przez wywiady państw obcych. Ochrona wojska realizowana były w formie zapobiegawczej właśnie poprzez profilaktykę kontrwywiadowczą.

Z dokumentów źródłowych pozostawionych przez WSW wynika, że profilaktyka kontrwywiadowcza dotyczyła zwalczania przestępczości w SZ PRL oraz zapobiegania penetracji obiektów wojskowych przez służby wywiadowcze państw kapitalistycznych. Jednym $\mathrm{z}$ aspektów pracy WSW było też zabezpieczenie obiektów wojskowych przed penetracją ze strony dyplomatów, cudzoziemców, osób postronnych oraz przeciwdziałanie naruszeniom zasad ochrony tajemnicy państwowej i służbowej. W Wojskowej Służbie Wewnętrznej istotą pracy profilaktycznej było niedopuszczenie do zjawisk negatywnych z punktu widzenia kontrwywiadowczej ochrony wojsk. Działalność profilaktyczna miała być ukierunkowana na sferę działań z pogranicza zagadnień wychowawczych, tak aby zmierzała do neutralizowania przyczyn i źródeł negatywnych.

Słowa kluczowe: Wojskowa Służba Wewnętrzna, kontrwywiad wojskowy, profilaktyka kontrwywiadowcza, komunizm

${ }^{1}$ Dr Arkadiusz Machniak reprezentuje Regionalne Towarzystwo Naukowe w Przeworsku, jest pracownikiem Wojska Polskiego, zajmuje się badaniami historii wywiadu i kontrwywiadu oraz szeroko rozumianym bezpieczeństwem; 37-200 Przeworsk, ul. Misiągiewicza 31, e-mail: amur5@tlen.pl 


\section{Wprowadzenie}

Wojskowa Służba Wewnętrzna (WSW) została powołana rozkazem Ministra Obrony Narodowej nr 01/MON z 10 stycznia 1957 r. Zgodnie z zarządzeniem Szefa Sztabu Generalnego nr 0013/ORG z 21 stycznia 1957 r. rozformowaniem Głównego Zarządu Informacji Wojska Polskiego (GZI WP) i utworzeniem nowych wojskowych służb miał się zająć szef WSW w terminie do 11 lutego 1957 r. (Kapuściak 2010: 15).

Funkcjonowanie wojskowych służb specjalnych w okresie PRL, szczególnie po 1956 r., ciągle stanowi zagadnienie mało rozpoznane, podobnie zresztą jak metodologia pracy operacyjnej tych służb. Wynika to m.in. stąd, że materiały dotyczące tej materii do niedawna nie były jeszcze, z różnych względów, dostępne do badań naukowych (Piotrowski 2008: 401). Badania naukowe prowadzone po 1990 r. nad komunistycznymi organami bezpieczeństwa, zarówno cywilnymi jak i wojskowymi, skutkowały ukazaniem się wielu publikacji charakteryzujących ich działalność. O bezpiece cywilnej, której okrucieństwa sygnują od dekad dwa skrótowce: UB oraz SB, wydaje się, że słyszał prawie każdy Polak. Rodacy mają o tych służbach wyrobione opinie, najczęściej negatywnie. Niewiele zaś albo prawie nic nie zachowało się w świadomości społecznej na temat WSW (Kowalski 2017: 8).

Działalność WSW wymaga dociekliwych badań i oceny. W niniejszym studium autor poddaje analizie jedną z metod pracy operacyjnej WSW, tak zwaną profilaktykę kontrwywiadowczą, będącą integralnym elementem metodyki czynności operacyjno-rozpoznawczych wykonywanych przez przedmiotową służbę. Czynności te nie były wytworem tej formacji, ich kształtowanie miało etapy wcześniejsze, co zostanie wykazane w toku wywodu. Przed 1990 r. powstało wiele opracowań dotyczących profilaktyki kontrwywiadowczej przeznaczonych dla hermetycznego grona odbiorców (np. oficerów WSW), które autor będzie cytować w niniejszym tekście. Należy jednak uwzględnić krytyczną ocenę tych źródeł, zważywszy na uwarunkowania okresu, w którym powstały, ich autorów (np. ostatni szef WSW gen. Edmund Buła) i oczywiste propagandowe przesłanie.

\section{Pojęcie profilaktyki kontrwywiadowczej w wojskowych organach bezpieczeństwa w latach 1945-1956}

Istotną sferą działalności organów informacji Wojska Polskiego w latach 1945-1956 była profilaktyka, w ramach której zapobiegano dezercjom, utracie broni i tajnych dokumentów oraz chroniono tajemnicę 
wojskową, a także rozpoznawano osoby o wrogim stosunku do ustroju komunistycznego utrzymujące kontakty ze środowiskiem żołnierzy zawodowych (Tkaczew 2007: 331). Osoby pozostające w kręgu zainteresowań organów informacji WP stanowiły tzw. bazą operacyjną. Zaliczano do niej wszystkich, którzy ze względu na swoją przeszłość, pochodzenie społeczne, znajomości, wyznawaną religię i światopogląd oraz nawyki mogli być ewentualnie wykorzystywani przez agentury „imperialistyczne”, na pewnym etapie, ewentualnie mogli ulec pływom „wrogiego elementu" z ich otoczenia (Palski 2016: 67).

Od stycznia 1946 r. organa informacji WP podejmowały działania operacyjne zmierzające do wcześniejszego wykrywania w wojsku zamiarów i przypadków dezercji, z bronią lub bez. Uzyskiwane informacje starano się wykorzystać do zapobiegania tym działaniom, między innymi poprzez przekazywanie zdobytej wiedzy dowódcom jednostek wojskowych (Tkaczew 2007: 333).

Jednym z głównych zadań statutowych organów informacji WP była ochrona szeroko rozumianej tajemnicy wojskowej. Od 1947 r. przed tą służbą stanęło nowe zadanie: wzmocnienie jednostek oraz obiektów wojskowych przed penetracją ze strony dyplomatów i cudzoziemców. W latach 1946-1948 w organach informacji WP część pracy profilaktycznej poświęcono kwalifikowaniu kandydatów do szkół i uczelni wojskowych oraz służby zawodowej, uznając jednocześnie, że ta sfera pracy profilaktycznej jest priorytetowa (Tkaczew 2007, passim). W celu odpowiedniego doboru kandydatów na podoficerów zawodowych oraz dla uniknięcia wytypowania wrogich elementów, „rozłożonych” moralnie lub przypadkowych Szef Głównego Zarządu Informacji WP polecił, aby przy okazji poboru okazać kompetentnym czynnikom daleko idącą pomoc. Przedstawiciele organów informacji WP zobowiązani zostali do udziału w komisjach kwalifikacyjnych na szczeblu pułku i dywizji, mieli też przekazywać swoim przełożonym dane na temat typowania niewłaściwych kandydatów (AIPN BU, 834/10: 81).

W związku z tym, że w kompaniach podchorążych rezerwy stwierdzano pojawianie się elementu „niepewnego”, Szef GZI WP zarządził, aby przy przedstawianiu wniosków o usunięcie i zdemobilizowanie podchorążych rezerwy za kompetentny podmiot opiniujący w tej sprawie uznać organa informacji WP, które sporządzały charakterystyki służbowe typowanych do usunięcia osób (AIPN BU, 834/10: 80). Oficerowie organów informacji WP zobowiązani byli do uczestnictwa w pracach komisji kwalifikacyjnych zajmujących się naborem kandydatów do szkół oficerskich. Skreśleniu podlegali ci, na których posiadano materiały kompromitujące. Oficerowie obiektowi mieli obowiązek przekazywać 
stosowne zadania obsługiwanej agenturze celem prowadzenia obserwacji kandydatów do szkół oficerskich w zakresie ujawnienia ewentualnych przypadków wprowadzenia w błąd komisji przez kandydata podającego fałszywe dane oraz bliższego naświetlenia oblicza moralno-politycznego kandydatów (AIPN BU, 834/13: 23).

Zwalczając wroga klasowego, terenowe organa informacji WP mogły poszczycić się sporymi ,sukcesami” w ujawnianiu i likwidowaniu grup i pojedynczych osób działających destrukcyjnie w wojsku. Osiągnięcia tej służby przejawiały się również $\mathrm{w}$ dziedzinie profilaktyki personalnej, co w ocenie oficerów tej formacji pomagało w dużej mierze w oczyszczeniu szeregów wojska z ,elementów wrogich i obcych klasowo". Należy stwierdzić, że w ocenie MON zasadniczy kierunek działalności organów informacji WP $\mathrm{w}$ zakresie walki $\mathrm{z}$ wrogiem był słuszny, a diagnoza sytuacji politycznej panującej $\mathrm{w}$ wojsku prawidłowa (AIPN BU, 834/18: 16).

Praca operacyjna w formie profilaktyki prowadzona była przez „oficera obiektowego". W języku operacyjnym komunistycznego kontrwywiadu wojskowego był to oficer prowadzący pracę operacyjną we wszystkich jej aspektach na terenie konkretnego obiektu wojskowego. Każdy oficer obiektowy zobowiązany był do opracowywania miesięcznego planu pracy oraz sprawozdania z jego realizacji. Plany te zatwierdzane były przez bezpośredniego przełożonego (AIPN BU, 834/10: 81).

Profilaktyka kontrwywiadowcza w pewien sposób kreowała wizerunek zagrożeń występujących $\mathrm{w}$ tym okresie w strukturach Sił Zbrojnych PRL. W prezentowaniu fałszywego obrazu rzeczywistości dużą rolę odgrywała specyficzna nomenklatura. Oficerowie organów informacji WP posługiwali się pojęciami w przemyślany sposób albo nadając słowom nowe znaczenia, albo przyporządkowując pewne środowiska do epitetów nacechowanych negatywnie bądź pozytywnie. We wszystkich swoich działaniach oficerowie obiektowi stosowali wzorce znane wcześniej z działań sowieckiego aparatu bezpieczeństwa (Pietrzak 2011: 230-231).

W materiałach GZI WP trudno jest zlokalizować informacje o skutecznych działaniach profilaktycznych wobec realnie zdiagnozowanych zagrożeń. W wielu dokumentach $\mathrm{z}$ tego okresu można natrafić na stwierdzenia typu: „nasilająca się penetracja wrogich służb”, „stwierdzone przypadki wrogiego działania" itp., które w ocenie piszącego te słowa mają charakter sentencji wprowadzającej do treści dokumentu, ale nie wskazują na wiarygodne pochodzenie źródła, jak również metody ich weryfikacji. 


\section{Profilaktyka kontrwywiadowcza WSW jako element pracy operacyjno-rozpoznawczej}

Powszechnie uważa się, że praca oficera kontrwywiadu wojskowego jest specyficzna i wymaga stosownych cech charakteru i umiejętności, m.in. łatwości nawiązywania kontaktów, szybkiej orientacji w sytuacji, elastycznego dostosowywania się do sytuacji i daru przekonywania, a jednocześnie budzenia u innych zaufania (Pacek 2012: 113).

Pracy profilaktycznej WSW poświęcony został cały rozdział II „Instrukcji o zasadach i formach pracy operacyjnej Wojskowej Służby Wewnętrznej” z 1 lipca 1965 r. (Kapuściak 2010: 123). Według jego zapisów WSW zobowiązana została do realizowania czynności w zakresie kontrwywiadowczej ochrony Sił Zbrojnych celem zapobiegania rozpoznawaniu wojska przez wywiady państw obcych, ochrony wojska przed oddziaływaniem „ośrodków dywersji ideologicznej”, krajowych „elementów antysocjalistycznych", wykrywania w wojsku przestępstw, zwłaszcza charakteru politycznego, zapobiegania zjawiskom i zdarzeniom wywierającym negatywny wpływ na gotowość bojową wojska. Cele i kierunki ochrony wojska realizowane były w formie zapobiegawczej właśnie poprzez profilaktykę kontrwywiadowczą (AIPNOR, 00341/35: 6-7).

Zakres przedsięwzięć profilaktycznych zawsze wynikał ze specyfiki ochranianej jednostki czy instytucji wojskowej, np. priorytetem w składnicy uzbrojenia i amunicji była ochrona środków pola walki (uzbrojenia), a w wojewódzkim sztabie wojskowym najważniejsza była ochrona informacji niejawnych. W tym zakresie oficer WSW realizował przedsięwzięcia wspierające utrzymanie wysokiego poziomu zdolności bojowej ochranianej jednostki czy instytucji wojskowej, gdyż na bieżąco informował dowódcę (szefa, komendanta) o wszelkich okolicznościach sprzyjających popełnieniu przestępstw z części wojskowej kodeksu karnego i proponował rozwiązania zmierzające do neutralizacji zagrożeń. Więcej niż 50\% zadań profilaktycznych oficer WSW realizował dzięki utrzymywaniu więzi ze „stanami osobowymi” ochranianych jednostek i instytucji wojskowych. Oficerowie WSW czynnie uczestniczyli we wszystkich przedsięwzięciach szkoleniowych w ochranianych jednostkach i instytucjach wojskowych (alarmy, szkolenia poligonowe, strzelania, szkolenie fizyczne, odprawy, uroczystości itp.). Z wyjeżdżającymi za granicę prowadzili rozmowy profilaktyczne (wyczulające) przed wyjazdem i po powrocie. Osoby posiadające dostęp do informacji stanowiących tajemnicę państwową podlegały osłonie kontrwywiadowczej. Oficerowie WSW prowadzili także szkolenia w zakresie ochrony infor- 
macji niejawnych. W razie zaginięcia dokumentów niejawnych lub utraty środków walki w ochranianej jednostce wojskowej oficer obiektowy włączał się w czynności poszukiwawcze prowadzone w ramach sprawy operacyjnego poszukiwania (K.L. 2017).

Z dokumentów źródłowych pozostawionych przez WSW wynika, że celem profilaktyki kontrwywiadowczej było zwalczanie przestępczości w SZ PRL, zapobieganie penetracji obiektów wojskowych przez służby wywiadowcze państw kapitalistycznych, jak również zabezpieczenie ich przed penetracją ze strony dyplomatów, cudzoziemców, osób postronnych, przeciwdziałanie naruszeniom zasad ochrony tajemnicy państwowej i służbowej, w szczególności w newralgicznych komórkach instytucji centralnych MON, sztabach okręgów wojskowych i rodzajów sił zbrojnych, sztabach związków operacyjnych i taktycznych, jednostkach specjalnych oraz wojskowych instytucjach naukowych. Ponadto działalność tej formacji ukierunkowana była na zapobieganie zaborowi broni, dezercji, ucieczkom za granice kraju, zaborowi mienia społecznego i niegospodarności, jak również innym zdarzeniom i wypadkom nadzwyczajnym (AIPNOR, 00341/35: 8).

Analizując dokumenty wytworzone przez WSW, a związane z profilaktyką kontrwywiadowczą, można stwierdzić, że służba ta w tym zakresie sporo uwagi i wysiłku poświęcała zagadnieniu ochrony tajemnicy wojskowej. W dokumentach szkoleniowych WSW odnajdujemy informacje wskazujące, iż ochrona tajemnicy wojskowej traktowana była jako jeden z priorytetów i obowiązków żołnierzy. W ramach działań profilaktycznych zalecano realizację niezbędnych czynności w stosunku do młodych żołnierzy wcielanych do zasadniczej służby wojskowej. Płaszczyzną realizacji tych wytycznych miały być organizowane spotkania z żołnierzami, prelekcje, zebrania aktywu partyjnego, w trakcie których wyjaśniano przepisy dotyczące ochrony tajemnicy wojskowej (AIPN BU, 2603/13461: 39).

Kolejną sferą rygorystycznego przestrzegania tajemnicy wojskowej były poligony i ćwiczenia wojskowe. Kadry wojskowe miały być regularnie szkolone $\mathrm{w}$ ramach profilaktyki kontrwywiadowczej w zakresie obserwacji ruchu osobowego w rejonie poligonu, zwłaszcza pojawiających się w okolicy w trakcie ćwiczeń pojazdów na dyplomatycznych numerach rejestracyjnych (tamże: 40). W ocenie WSW było to przedsięwzięcie złożone i trudne. Zakładano, że ćwiczenia wojskowe powodują wzmożoną aktywność obcego wywiadu i jego agentury w okolicy poligonu polegającą na działaniach penetracyjnych. W związku z tym w ramach profilaktyki kontrwywiadowczej zalecano formowanie na okres poligonu i ćwiczeń tzw. grup zabezpieczających, składających się 
z wytypowanej kadry żołnierskiej WSW, która ochraniała jednostki wojskowe w warunkach stacjonarnych (AIPNOR, 00341/35: 81).

Profilaktyka kontrwywiadowcza koncentrowała się również na przedsięwzięciach związanych z ochroną tajemnicy państwowej i służbowej. Ochrona ta w wydaniu WSW polegała na neutralizowaniu działalności obcych wywiadów oraz osób nieupoważnionych w zakresie pozyskiwania wiadomości o wojsku i odpowiednim zabezpieczeniu w tym zakresie obiektów wojskowych (tamże: 52). W ramach profilaktyki kontrwywiadowczej zalecano szczególną ochronę dokumentów. WSW wskazywała, że bezprawne ich udostępnianie osobom niedopuszczonym do prac tajnych jest surowo zabronione, bo może skutkować odpisaniem ich treści lub sfotografowaniem (AIPN BU, 2603/13461: 41). Żołnierze posiadający pełny dostęp do wiadomości z dziedziny gotowości bojowej lub planowania bojowego i mobilizacyjnego podlegali szczególnej profilaktycznej ochronie kontrwywiadowczej. W zaleceniach do pracy w profilaktyce kontrwywiadowczej wskazywano, że nadrzędnym celem w tym przypadku jest niedopuszczenie do werbunku przez obcy wywiad lub dopuszczenie do skompromitowania osoby, co w konsekwencji i tak zagrażało potencjalnym werbunkiem (AIPNOR, 00341/35: 57).

Oficer WSW w ramach profilaktyki kontrwywiadowczej był zobowiązany do monitorowania kontaktów kadry z osobami przebywającymi w tzw. krajach kapitalistycznych. W ramach tego zadania przeprowadzał rozmowy z żołnierzami, członkami ich rodzin i pracownikami cywilnymi wyjeżdżającymi na Zachód. Rozmowy te odbywały się zarówno przed wyjazdem celem udzielenia instruktażu co do sposobów zachowania się, jak i po powrocie do kraju dla wyjaśnienia wszelkich okoliczności związanych z wyjazdem poza granice Polski. Ponadto oficer tej formacji prowadził rozmowy z ustalonymi osobami, które utrzymywały kontakty osobiste i listowne $\mathrm{z}$ osobami zamieszkałymi w krajach kapitalistycznych, celem wyjaśnienia charakteru tych kontaktów (AIPN BU, 2603/13461: 63).

W ocenie kierownictwa WSW istotą pracy profilaktycznej było niedopuszczenie do zjawisk negatywnych z punktu widzenia kontrwywiadowczej ochrony wojsk. Działalność profilaktyczna należała więc do szeroko rozumianej problematyki wychowawczej i była skoncentrowana na neutralizacji przyczyn i źródeł negatywnych zachowań (AIPN BU, 01304/120: 17). Profilaktyka kontrwywiadowcza miała nie dopuszczać do zaistnienia okoliczności sprzyjających prowadzeniu przestępczej działalności w Siłach Zbrojnych. Głównym zadaniem w tym zakresie było ujawnianie i likwidowanie przesłanek sprzyjających naruszeniom 
zasad pracy ochranianych wojsk. WSW w tej dziedzinie miała realizować czynności polegające na sygnalizowaniu negatywnych zjawisk (tamże: 18-19).

Oddziaływanie w trakcie pracy szkoleniowej i wychowawczej w zakresie profilaktyki kontrwywiadowczej uwzględniało następujące płaszczyzny kształtowania postaw żołnierzy i pracowników wojska. Pierwsza - poznawcza obejmowała obszar przekazywania informacji o zagrożeniach i sposobach przeciwdziałania. Druga - emocjonalna miała wywoływać pozytywny stosunek do przedsięwzięć profilaktycznych. Trzecia - behawioralna koncentrowała się wokół kształtowania nawyków określonych reakcji w kontekście konkretnych zagrożeń (AIPN BU, 2603/8176: 84).

\section{Wybrane kierunki i metodyka profilaktyki kontrwywiadowczej}

$\mathrm{Na}$ podstawie analizy wytworzonych w latach 1957-1990 przez WSW materiałów źródłowych dotyczących profilaktyki kontrwywiadowczej autor wyselekcjonował typowe przykłady i kierunki profilaktyki kontrwywiadowczej w niektórych rodzajach Sił Zbrojnych przed $1990 \mathrm{r}$.

W wojskach lotniczych profilaktyka kontrwywiadowcza miała na celu m.in. niedopuszczenie do zdrady kraju i wykrywanie symptomów wskazujących na ewentualne zamiary lub próby uprowadzenia samolotu. Prowadzona była w celu rozpoznawania kandydatów na pilotów oraz samych pilotów, ze szczególnym ustaleniem ich potencjalnych powiązań z cudzoziemcami, głównie z krajów kapitalistycznych. Realizowano ją celem zapobieżenia wypadkom lotniczym, ujawniania przygotowań do aktów dywersji lub sabotażu. Ustalano na jej podstawie uszkodzenia lub niesprawności sprzętu lotniczego, co mogło być w ocenie WSW przyczyną celowego działania personelu lotniczego, który niewłaściwie wykonywał obowiązki służbowe (AIPN BU, 001834/544: 15). Profilaktyka kontrwywiadowcza w lotnictwie realizowana była również w zakresie przeciwdziałania penetracji jednostek wojskowych przez obcy wywiad, ochrony tajemnicy państwowej, zapobiegania dezercjom, zabezpieczenia ćwiczeń i poligonów oraz innych przedsięwzięć z udziałem żołnierzy (tamże: 21).

Profilaktyka kontrwywiadowcza w wojskach lotniczych zgodnie z założeniami miała być zespołem czynności realizowanych w sposób planowy i systematyczny. Obowiązywała zasada, że całość dokumentów dotyczących określonych zdarzeń (np. w formie meldunków czy też notatek służbowych) będących przedmiotem działalności profilaktycznej 
oficera obiektowego była systematyzowana i przechowywana w teczce danego obiektu (AIPN BU, 2603/8244: 10). Prowadzono też teczki osobowych źródeł informacji (OZI) pozyskanych przez oficerów obiektowych. Ponadto zakładane były teczki spraw operacyjnych w postaci spraw operacyjnego zainteresowania i spraw operacyjnego sprawdzenia. Te dwie ostatnie kategorie zakładane były na podstawie materiałów wstępnych (A.P. 2017).

Profilaktyka kontrwywiadowcza była rodzajem czynności zapobiegawczych mających również na celu pewną formę oddziaływania psychicznego. Jej skuteczność w tym wymiarze obwarowana była systematyką działań i aktywnym współudziałem kadry zawodowej i żołnierzy służby zasadniczej (AIPN BU, 2603/8244: 54).

Zrozumienie zasadności prowadzenia działań profilaktycznych wymagało cyklicznych szkoleń stanów osobowych danej jednostki i obiektu wojskowego. W ich trakcie oficer WSW miał za zadanie dążyć do wyjaśnienia wszelkich zawiłości problemowych spraw i tematów (tamże: 56). Biorąc pod uwagę szczególne postrzeganie przez WSW charakteru wojsk lotniczych, oceniano, że profilaktyka kontrwywiadowcza jest istotnym elementem metodyki operacyjnej zmierzającej do wykrywania, zapobiegania i likwidowania symptomów sprzyjających powstawaniu przesłanek do wypadków i katastrof lotniczych oraz innych zjawisk godzących w gotowość bojową jednostki, dyspozycyjność jej personelu, bezawaryjność eksploatowanego sprzętu i zabezpieczenie lotów statków powietrznych. W praktyce profilaktyka powinna doprowadzić do czynnego i wielokierunkowego zapobiegania przesłankom powstania negatywnych zjawisk, takich jak ucieczka personelu z uprowadzeniem samolotu poza granice kraju, ujawnienie tajemnicy, katastrofa czy zabór środków pola walki (AIPN BU, 001834/2929: 22-23).

Istotnym elementem w profilaktyce kontrwywiadowczej było wykorzystanie OZI. Tajnych współpracowników pozyskiwano na podstawie motywów „ideowo-politycznych”, zainteresowania materialnego lub osobistego, dowodów przestępczej działalności lub materiałów kompromitujących. Werbowano ich w środowisku żołnierzy, pracowników cywilnych, rodzin żołnierzy, a w uzasadnionych przypadkach innych osób, w tym również zamieszkałych na stałe lub czasowo w państwach kapitalistycznych. Nie było wolno pozyskiwać do współpracy z WSW: generałów, oficerów na etatach generalskich, oficerów politycznych, prokuratorów, sędziów, sekretarzy instancji partyjnych i członków PZPR. Od powyższych wyłączeń możliwe były odstępstwa ze względu na - jak to określano - potrzeby kontrwywiadowcze, ale wymagały one zgody wyższych przełożonych (Kapuściak 2010: 288-289). 
Tajny współpracownik zawsze podlegał rejestracji w ewidencji operacyjnej WSW i otrzymywał konkretny numer rejestracyjny. Przy podjęciu współpracy z tą kategorią informatorów oficerowie WSW dążyli zazwyczaj do uzyskania pisemnego, własnoręcznego potwierdzenia woli współpracy. Tajny współpracownik mógł być kontrolowany przez inne OZI, a w zależności od potrzeby nawet środkami techniki operacyjnej. Spotkania z tajnym współpracownikiem organizowano z zasady w lokalach kontaktowych poza jednostką wojskową lub w tzw. miejscach spotkań na terenie jednostki. $Z$ reguły było to miejsce ustronne wybrane przez oficera prowadzącego, które gwarantowało dobry przebieg spotkania. Tajny współpracownik WSW przekazywał informacje w formie ustnej lub pisemnej. Preferowane było odbieranie meldunku napisanego własnoręcznie przez raportującą osobę. Spotkania z OZI dokumentowane były przez oficera prowadzącego w formie notatki służbowej. Tajny współpracownik otrzymywał wynagrodzenie w postaci pieniędzy lub nagrody rzeczowej. Odbiór wynagrodzenia zawsze musiał być pokwitowany przez OZI. Dokumentacja służbowa dotycząca każdego tajnego współpracownika kompletowana była w teczce personalnej oraz teczce pracy. Nie było oficjalnych wytycznych na temat liczby OZI, których musiał obsługiwać konkretny oficer prowadzący. Uwarunkowane to było sytuacją operacyjną na terenie obiektu lub specyfiką danego zjawiska. Przyjęta ,norma” przewidywała jednak, aby oficer WS pilotował około 10-12 tajnych współpracowników (A.P. 2017).

W profilaktyce kontrwywiadowczej oficer obiektowy zobowiązany był do takiego doboru i ukierunkowania zadań dla OZI, aby uzyskać zakładany efekt, tj. informacje. Odpowiednie stawianie zadań i rozliczanie z nich OZI wpływało nie tylko na jakość pozyskiwanych informacji, ale też na psychikę informatorów i jakość współpracy (AIPN BU, 001834/2929: 45). Rola OZI w pracy profilaktycznej oficerów WSW wynikała z zadań formułowanych w zarządzeniach i wytycznych stawianych oficerom obiektowym przez przełożonych oraz z sytuacji operacyjnej w jednostce lub obiekcie wojskowym (tamże: 117).

Głównym zadaniem oficera obiektowego WSW wykonującego obowiązki profilaktyczne w ramach Wojsk Obrony Powietrznej Kraju było uzyskiwanie informacji wyprzedzających dotyczących potencjalnego wystąpienia przesłanek do wypadków nadzwyczajnych, wydarzeń i zjawisk mających wpływ na gotowość bojową, dyscyplinę i nastroje stanu osobowego, co w konsekwencji obligowało go do przekazywania tych informacji dowództwu ochranianego obiektu wojskowego (AIPN BU, 001834/2239: 88). 
Istotną płaszczyzną działania $\mathrm{w}$ ramach profilaktyki kontrwywiadowczej było szkolenie żołnierzy ochranianej jednostki wojskowej. W jego trakcie oficer WSW realizował czynności mające na celu wyrobienie wśród wojskowych i pracowników cywilnych poczucia odpowiedzialności za przeciwdziałanie zjawiskom negatywnym, przestępczym i potencjalnej wrogiej działalności oraz zjawiskom godzącym w podstawy gotowości bojowej jednostek wojskowych (tamże: 89). W takich przypadkach aktywność profilaktyczna oficera obiektowego sprowadzała się w praktyce do inspirowania wsparcia ze strony dowództwa danej jednostki i jej aparatu partyjno-politycznego. Powinna być prowadzona zgodnie z sytuacją operacyjną na terenie danego obiektu, a $\mathrm{w}$ jej ocenie oficer WSW miał ściśle współpracować z wymienionymi strukturami partyjno-politycznymi (tamże: 93-94).

Oficer WSW w trakcie realizowania profilaktyki kontrwywiadowczej miał obowiązek eliminować potencjalne zagrożenia związane $\mathrm{z}$ nieprawidłowościami $\mathrm{w}$ sferze ochrony tajemnicy państwowej i służbowej. Do jego zadań należało kształtowanie poczucia odpowiedzialności stanów kadrowych w jednostkach wojskowych w tym zakresie. Oficer WSW miał zapewnić sobie wiarygodny przekaz informacji o potencjalnych nieprawidłowościach i wszelkich uwarunkowaniach sprzyjających ewentualnym zagrożeniom na tej płaszczyźnie. W ramach profilaktyki miał za zadanie rozpoznać ewentualne osoby przejawiające nieuzasadnione zainteresowanie wiadomościami niejawnymi oraz dążyć do wyjaśnienia celów i motywów tych postaw. Powinien w ramach profilaktyki opiniować osoby przed ich potencjalnym dopuszczeniem do prac tajnych oraz wnioskować o usuwanie ze stanowisk z dostępem do informacji klasyfikowanych osób, które nie dawały rękojmi zachowania tajemnicy (AIPN BU, 001834/3172: 51).

Przeciwdziałanie nielegalnemu zaborowi broni, amunicji i materiałów wybuchowych było jednym z istotniejszych elementów profilaktyki kontrwywiadowczej WSW. Potencjalne nielegalne pozyskanie środków pola walki wpływało na wzrost zagrożeń o podłożu kryminalnym. Głównym zadaniem profilaktycznym było pozyskanie przez oficera obiektowego WSW ewentualnych informacji wskazujących na występowanie negatywnych przesłanek $\mathrm{w}$ tym zakresie i ich potencjalne neutralizowanie. Istotnym celem było również zdobycie informacji wyprzedzających o ewentualnych zamiarach związanych z zaborem środków bojowych (tamże: 54). Właściwe zabezpieczenie broni, amunicji czy też środków pozoracji pola walki wymagało od oficera WSW uzyskania wszechstronnych, wiarygodnych informacji o stwierdzanych nieprawidłowościach na terenie obiektu wojskowego (tamże: 58). Zadaniem ofi- 
cera obiektowego było ujawnianie tego typu przesłanek oraz w dalszej kolejności inspirowanie dowództwa do podejmowania szybkich reakcji zapobiegawczych (tamże: 61).

Olbrzymie znaczenie w działalności profilaktycznej miało zagadnienie kontaktów członków kadry wojskowej i ich rodzin z krajami kapitalistycznymi. Kontakty te postrzegane były przez WSW jako główna płaszczyzna wykorzystywana przez obce wywiady (AIPN BU, 001834/ 2209: 26). W tym zakresie praca profilaktyczna miała trzy zasadnicze kierunki. Pierwszy polegał na okresowym sprawdzaniu wyjaśnianych kontaktów, kolejny na prowadzeniu rozmów z osobami wyjeżdżającymi do krajów kapitalistycznych oraz przyjeżdżającymi z ich obszaru, a finalny kierunek obejmował kształtowanie świadomości stanu kadrowego jednostki wojskowej o zagrożeniu, jakie może ewentualnie wystąpić w związku z nawiązaniem kontaktu z cudzoziemcami. Dodatkową formą pracy profilaktycznej były rozmowy indywidualne z żołnierzami ochranianej jednostki w trakcie rutynowych działań oficera obiektowego WSW. Ten zobowiązany był do ścisłej współpracy z kadrą pododdziałów, w ramach której były wymieniane informacje i wyjaśniane sytuacje dotyczące podwładnych, takie jak np. utrzymywanie korespondencji z cudzoziemcami czy też wizyty cudzoziemców w domach rodzinnych kadry wojskowej (tamże: 31).

$\mathrm{W}$ ramach profilaktyki kontrwywiadowczej związanej z rozpoznawaniem kontaktów kadry wojskowej zalecano ścisłą współpracę z organami SB. Oficerowie WSW zobowiązani byli do okresowej analizy wszelkich kontaktów, które były już wcześniej wyjaśnione, celem ich ponownej weryfikacji (tamże: 32 ). Współpraca ta wymagała jednak zachowania szczególnej ostrożności, gdyż organy SB miały skłonność do przenoszenia swoich zainteresowań na obiekty wojskowe ochraniane przez WSW (K.L. 2017). Oficjalne polecenia kierownictwa WSW wskazywały, w jaki sposób prowadzić i dokumentować kontakty z lokalnymi strukturami aparatu SB. W praktyce jednak oficerowie WSW na podstawie swoich dobrych i długoletnich kontaktów o charakterze zawodowo-towarzyskim z funkcjonariuszami SB zdobyte informacje przekazywali ustnie i w podobny sposób otrzymywali dane dotyczące kadry wojskowej. Informacje wymieniane tą drogą nie były odnotowywane w dokumentacji operacyjnej, a przełożeni w poszczególnych jednostkach organizacyjnych WSW po cichu akceptowali takie metody pracy (A.P. 2017).

Oceniano, że zasadniczym warunkiem skuteczności działań profilaktycznych było posiadanie informacji o aktualnym stanie rzeczywistych zagrożeń i możliwości ich rozwoju. Pozwalało to określić konkretne 
potrzeby odnoszące się do działań wobec poszczególnych środowisk wojskowych, a w ich neutralizacji zastosować wystarczające siły i środki. Całokształt działalności profilaktycznej miał być ukierunkowany na stymulowanie zakładanych zachowań kadry żołnierskiej. Ten cel realizowano poprzez kształtowanie wewnętrznych mechanizmów kontroli kadry wojskowej, wzmacniając stan świadomości, głównie w zakresie znajomości funkcjonowania ówczesnego systemu bezpieczeństwa państwa (AIPN BU, 1636/93: 99-100). Zagadnienia profilaktyczne realizowane były dla ochrony wojska poprzez stałe i systematyczne neutralizowanie środowisk podatnych na dokonywanie przestępstw lub znajdujących się $\mathrm{w}$ zakresie potencjalnej wrogiej działalności (AIPN BU, 2603/8254: 17).

\section{Zakończenie}

WSW przejęła kadry, struktury i metody pracy po służbach Informacji WP. Znacznie ograniczono jej możliwości w stosunku do poprzedniczki. Formalnie WSW miała odgrywać jedynie rolę prewencyjną i informacyjną, do jej zadań miało należeć na przykład informowanie o przejawach religijności czy zwalczanie opozycji politycznej, szczególnie w latach osiemdziesiątych, i prowadzenie działalności operacyjnej w środowiskach cywilnych. Miało to decydujące znaczenie dla podjęcia decyzji o rozwiązaniu WSW (Piotrowski 2008: 39).

Profilaktyka kontrwywiadowcza WSW miała kształtować świadomość współodpowiedzialności kadry wojskowej i pracowników cywilnych za bezpieczeństwo oraz ujawniać i likwidować wszelkie ujemne zjawiska rzutujące na poziom bojowy wojska (AIPN BU, 2603/13461: 52). Jak wskazano w niniejszym tekście, rozwijana była w dużym stopniu w sferze działań wychowawczych, tak aby zmierzała do usuwania przyczyn i źródeł negatywnych zjawisk (AIPN BU,2603/12656: 111).

Wyznaczane cele i zadania realizowane $\mathrm{w}$ ramach profilaktyki kontrwywiadowczej determinowały jej szczególne znaczenie w całokształcie działalności WSW. Profilaktyka kontrwywiadowcza obejmowała wszystkie dziedziny życia wojskowego na wszystkich szczeblach organizacyjnych Sił Zbrojnych PRL. Specyfika profilaktyki kontrwywiadowczej polegała na tym, że podejmowane w jej ramach czynności realizowane były przy wykorzystaniu środków i metod dostępnych w ramach pracy operacyjnej WSW. Tym samym teoretycznie zapewniała tej służbie rozpoznanie sytuacji w poszczególnych jednostkach wojskowych i komórkach organizacyjnych instytucji wojskowych. 
Analizując materiały źródłowe WSW dotyczące profilaktyki kontrwywiadowczej, należy zauważyć indoktrynacyjny charakter działań, jakie w jej ramach realizowali oficerowie tej służby. Materiały źródłowe wskazują, że miała ona te same elementy, założenia i metodykę działania we wszystkich rodzajach wojsk. Trudno jednocześnie w tych materiałach wytypować - a znaczna ich część to prace naukowe czy biuletyny poglądowe - konkretne przykłady i efekty profilaktyki kontrwywiadowczej. Dominuje tendencja teoretyzowania i udzielania wskazówek. Niewątpliwie był to materiał poglądowy w procesie kształcenia oficerów WSW i spełniał wszelkie przesłanki do kreowania i umacniania obowiązującej w szeregach tej służby „,zwartości ideowej”.

\section{Literatura}

AIPN BU, sygn. nr 834/10, Pismo Szefa Oddziału III Gtównego Zarządu Informacji do wszystkich Szefów Okręgowych Zarządów Informacji z dnia 22 stycznia 1949 r.

AIPN BU, sygn. nr 834/10, Pismo Szefa Oddziatu III Gtównego Zarząu Informacji Wojska Polskiego do wszystkich Szefów Okręgowych Zarzadów Informacji z dnia 17 stycznia $1949 \mathrm{r}$.

AIPN BU, sygn. nr 834/13, Zarządzenie nr 75/D Szefa Gtównego Zarządu Informacji Wojska Polskiego z dnia 15 lutego $1950 \mathrm{r}$.

AIPN BU, sygn. nr 834/18, Rozkaz nr 9/Inf. Ministra Obrony Narodowej z dnia 19 grudnia $1950 r$.

AIPN BU, sygn.2603/12656, Psychologiczne aspekty profilaktyki kontrwywiadowczej z. $1973 \mathrm{r}$.

AIPN BU, sygn. nr 01304/120, Gtówne problemy profilaktyki kontrwywiadowczej z 1974 r.

AIPN BU, sygn. nr 2603/13461, Praktyczne wskazówki do pracy z zakresu profilaktyki kontrwywiadowczej z $1975 \mathrm{r}$.

AIPN BU, sygn. nr 2603/8244, Psychologiczne problemy profilaktyki kontrwywiadowczej $w$ jednostkach lotniczych z $1976 r$.

AIPN BU, sygn. nr 001834/544, Rola profilaktyki kontrwywiadowczej wśród personelu latającego i technicznego jednostek lotniczych Wojsk Lotniczych $i$ Wojsk Ochrony Przeciwlotniczej Kraju z 1977 r.

AIPN BU, sygn. 001834/2209, Praca oficera operacyjnego Wydzialu WSW Jednostek Wojskowych Ministerstwa Spraw Wewnętrznych w zakresie profilaktyki kontrwywiadowczej na przykladzie Eużyckiej Brygady Wojsk Ochrony Pogranicza z 1984 r.

Archiwum Instytutu Pamięci Narodowej, Oddział Rzeszów, sygn. nr 00341/35, Profilaktyka kontrwywiadowcza z $1985 \mathrm{r}$.

AIPN BU, sygn. nr 2603/8254, Profilaktyka kontrwywiadowcza z 1985 r.

AIPN BU, sygn. nr 001834/2239, Problemy kontrwywiadowczej profilaktyki w pracy oficera obiektowego kontrwywiadu wojskowego na przykładzie zwiazku taktycznego Wojsk Obrony Powietrznej Kraju z 1986 r.

AIPN BU, sygn. nr 2603/8176, Elementy profilaktyki kontrwywiadowczej z 1989 r.

AIPN BU, sygn. nr 001834/2929, Rola osobowych źródet informacji w realizacji zadań profilaktyki kontrwywiadowczej w jednostkach wojsk lotniczych z 1989 r. 
AIPN BU, sygn. nr 1636/93, Wprowadzenie do profilaktyki kontrwywiadowczej. Uwarunkowania, modele, zasady realizacji z $1989 \mathrm{r}$.

AIPN BU, sygn. nr 001834/3172, Wiodące kierunki i metodyka profilaktyki kontrwywiadowczej oficera obiektowego na przyktadzie batalionu granicznego Wojsk Ochrony Pogranicza Placówki Kontroli Świnoujście z 1989 r.

A.P. 2017, Relacja z dnia 23 marca 2017 r. byłego oficera WSW (dane w dyspozycji autora artykułu).

Kapuściak B. (oprac.), 2010, Instrukcje pracy kontrwywiadowczej Wojskowej Stużby Wewnętrznej wraz z instrukcjami prowadzenia dokumentacji $i$ ewidencji (19571990), Wyd. AKADE, Kraków.

K.L. 2017, Relacja z dnia 3 maja 2017 r. bytego oficera WSW (dane personalne w dyspozycji autora artykułu).

Kowalski L., 2017, Krótsze ramię Moskwy, historia kontrwywiadu wojskowego PRL, Wyd. Fronda PL sp. z o.o., Warszawa.

Pacek B., 2012, Osobowość a efektywność zawodowa oficerów kontrwywiadu [w:] Stużby specjalne $w$ systemie bezpieczeństwa państwa. Przeszłość - teraźniejszość przyszłość. Materiały i studia, red. A. Krzak, D. Gibas-Krzak, t. II, Wyd. Wojskowe Centrum Edukacji Obywatelskiej, Szczecin-Warszawa.

Palski Z., 2016, Informacja Wojska Polskiego 1943-1957,Wyd. Agencja Wydawnicza $\mathrm{CB}$, Warszawa.

Piotrowski P., 2008, Uwagi o funkcjonowaniu i metodologii pracy operacyjnej Zarzadu II Sztabu Generalnego WP oraz Wojskowej Stużby Wewnętrznej Jednostek Wojskowych MSW [w:] Osobowe źródła informacji - zagadnienia metodologicznoźródtoznawcze, red. F. Musiał, Wyd. Towarzystwa Naukowego „Societas Vistulana", Kraków.

Pietrzak A., 2011, Główny Zarząd Informacji wobec oflagowców 1949-1956, Wyd. LTW Łomianki, Warszawa.

Piotrowski P., Wojskowa Stużba Wewnętrzna 1957-1989, Komentarze Historyczne (wydanie internetowe).

Tkaczew W., 2007, Organa informacji Wojska Polskiego 1943-1956. Kontrwywiad Wojskowy, Wyd. Bellona, Warszawa.

\section{Counterintelligence prevention in the activities of the Internal Military Service}

\section{Abstract}

WSW replaced the Main Directorate of Information in the structures of the Armed Forces that were feared and hated. WSW was to play only a preventive and informative role. These assumptions, however, bear the mark of a totalitarian system. The WSW was assigned supervisory tasks in other areas. WSW was obliged to carry out activities in the field of counterintelligence protection of the Armed Forces in order to prevent recognition of the army by the intelligence services of foreign states. The objectives and fields of activity of military protection were implemented in a preventive form through counterintelligence prevention. The source documents left by the WSW show that counterintelligence prevention was carried out to combat crime in the People's Republic of Poland, and to prevent the penetration of military facilities by the intelligence services of capitalist countries. Moreover, they prevented violations of the principles of protection of state 
and official secrets by diplomats, foreigners and bystanders. In WSW, the essence of preventive work was to prevent the emergence of negative phenomena from the point of view of counterintelligence protection of troops. Preventive activity should be directed at the sphere of activities from the borderline of educational issues, so that it aims at neutralizing negative causes and sources.

Key words: Internal Military Service, military counterintelligence, prevention, communism 